\title{
BENTUK PENYALAHGUNAAN WEWENANG PEJABAT PEMERINTAH YANG TIDAK DAPAT DIPIDANA
}

\author{
Moh. Alfatah Alti Putra \\ Ilmu Hukum, Sekolah Tinggi Ilmu Hukum Amsir Parepare \\ Email: alfatahaltiputra@gmail.com
}

\begin{abstract}
The shape of the error in the use of authority (misuse of authority), is actually a different act of understanding with abuse (abuse of power) that relates to whether or not convicted the form of abuse of authority. Research conducted is research using Library Research Methods. Forms of Abuse of Authority that can not be criminalized is an abuse of authority with the form of misuse of authority, while in abuse of authority that can be criminalized there is a form of error with a pattern of deliberateness as a purpose or guilty mind (mens rea).The form of Abuse of Authority that cannot be penalized is the abuse of authority in a form beyond authority and arbitrary, because in its sense in the Government Administration Law there is no transition of purpose from granting authority unless it is an administrative error with the form of misuse of authority. While in the Abuse of Authority that can be criminalized form of abuse of authority in accordance with the understanding in the Law of Government Administration on interfering with authority that can be followed up with criminalization when the transfer of authority objectives accompanied guilty mind (Mens Rea) in the form of errors with a pattern of deliberateness as the intention to seek profit that harms the state's finances or the economy of the State.
\end{abstract}

Keywords: abuse of authority, government officer, guilty mind.

\begin{abstract}
Abstrak
Bentuk kesalahan dalam penggunaan wewenang (misuse of authority), sebenarnya merupakan perbuatan yang beda pengertian dengan penyalahgunaan wewenang (abuse of power) sehingga berkaitan dengan dapat tidaknya dipidana bentuk penyalahgunaan wewenang tersebut. Penelitian yang dilakukan adalah penelitian dengan menggunakan metode penelitian kepustakaan (Library Research Methods). Bentuk Penyalahgunaan Wewenang yang tidak dapat dipidana merupakan penyalahgunaan wewenang dengan wujud kesalahan penggunaan wewenang (misuse of authority), sedangkan dalam Penyalahgunaan Wewenang yang dapat dipidana didalamnya terdapat bentuk kesalahan dengan corak kesengajaan sebagai maksud atau niat jahat (mens rea) untuk menyalahgunakan wewenang. Bentuk Penyalahgunaan Wewenang yang tidak dapat dipidana adalah penyalahgunaan wewenang dengan bentuk melampaui wewenang dan sewenang-wenang, karena dalam pengertiannya di Undang Undang Administrasi Pemerintahan tidak ada peralihan tujuan dari pemberian wewenang terkecuali merupakan kesalahan administrasi dengan wujud kesalahan penggunaan wewenang (misuse of authority). Sedangkan dalam Penyalahgunaan Wewenang yang dapat dipidana bentuk penyalahgunaan wewenangnya sesuai dengan pengertian dalam Undang Undang Administrasi Pemerintahan tentang mencampuradukkan wewenang yang dapat ditindaklanjuti dengan pemidanaan ketika peralihan tujuan wewenang itu disertai Niat Jahat (Mens Rea) dalam bentuk kesalahan dengan corak kesengajaan sebagai maksud untuk mencari keuntungan yang merugikan keuangan Negara atau perekonomian Negara.
\end{abstract}

Kata kunci: Penyalahgunaan Wewenang, Pejabat Pemerintah, Niat Jahat. 


\section{PENDAHULUAN}

Setiap pemberian wewenang kepada suatu badan atau kepada pejabat administrasi negara selalu disertai tujuan dan maksud diberikannya wewenang itu, sehingga penerapan wewenang itu harus sesuai dengan tujuan dan maksud diberikannya wewenang tersebut. Dalam hal penggunaan wewenang yang tidak sesuai dengan tujuan dan maksud pemberian wewenang, maka hal itulah yang merupakan penyalahgunaan wewenang.

Dalam penggunaaan wewenang pejabat, dimungkinkan terjadinya kesalahan dalam penggunaan wewenang (misuse of authority). Kesalahan penggunaan wewenang ini terjadi karena ketidakcermatan pejabat dalam membuat atau melakukan keputusan. Meskipun merupakan kesalahan administrasi, kesalahan penggunaan wewenang (misuse of authority) pada praktiknya terkadang disamaartikan dengan penyalahgunaan wewenang (abuse of power). Dimana ketika pejabat pemerintah dianggap melakukan penyalahgunaan wewenang (abuse of power), konsekuensinya tidak hanya sanksi administrasi saja, tapi dimungkinkan mendapat sanksi pidana. Padahal pemidanaan sebagai primum remedium seharusnya tidak perlu dilakukan, terlebih terhadap hal-hal yang masih dapat diperbaiki.

Terhadap suatu kesalahan administrasi atau kesalahan prosedur dalam pengambilan suatu keputusan/tindakan, dapat dilakukan pembatalan atas keputusan/tindakan pejabat pemerintah tersebut atau keputusan/tindakan itu dianggap tidak sah, sehingga terhadap keputusan/tindakan dapat dilakukan perbaikan dengan maksud mengembalikan pada prosedur yang seharusnya. Pejabat pemerintah yang melakukan kesalahan administrasi juga dapat dikenakan sanksi administrasi mulai dari sanksi peringatan, mutasi, demosi bahkan sampai diberhentikan dari jabatannya.

Penyalahgunaan Wewenang yang termasuk tindak pidana korupsi, merupakan perbuatan yang disertai maksud tertentu, dimana ada maksud untuk memperkaya atau menguntungkan diri sendiri atau orang lain atau suatu koorporasi, dengan cara sengaja 
menyalahgunakan wewenang yang melekat pada jabatan atau kedudukannya, untuk tujuan lain selain daripada tujuan diberikannya wewenang tersebut, yang berdampak merugikan keuangan atau perekonomian negara. Maka sangat penting menilai penggunaan wewenang pejabat pemerintah, apakah dilakukan dengan penyalahgunaan wewenang (abuse of power) yang dapat dipidana ataukah merupakan kesalahan penggunaan wewenang (misuse of authority) yang tidak perlu untuk dipidana.

Pemidanaan penyalahgunaan kewenangan menurut Undang-Undang Pemberantasan Tindak Pidana Korupsi tidaklah harus terburu-buru dilakukan, karena pada hakikatnya pemidanaan merupakan upaya/sanksi terakhir (ultimum remedium), terlebih lagi telah ada pengawasan dan pengujian penyalahgunaan wewenang yang diatur dalam Undang-Undang Administrasi Pemerintahan sebagai langkah pencegahan dan filterisasi penyalahgunaan wewenang yang berwujud kesalahan penggunaan wewenang (misuse of authority) yang tidak harus dipidana.

Pemidanaan dengan pendekatan Primum Remedium kepada penggunaan wewenang pejabat pemerintah, hanya berdampak kepada keragu-raguan pejabat pemerintah yang berwenang dalam menggunakan wewenangnya dan bisa berakibat pada perlambatan pengambilan keputusan yang tentunya akan mempengaruhi pelayanan terhadap masyarakat, laju pembangunan, bahkan stagnansi pemerintahan. Untuk itu perlu adanya harmonisasi penegakan hukum antara penanganan penyalahgunaan wewenang pejabat pemerintah menurut Undang Undang Administrasi Pemerintahan dan penanganan penyalahgunaan kewenangan sebagaimana yang diatur dalam Undang Undang Pemberantasan Tindak Pidana Korupsi.

\section{METODE PENELITIAN}


Penelitian tulis ini adalah merupakan tipe penelitian normatif, untuk itu sangat dibutuhkan data-data yang relevan dengan materi penulisan untuk memperoleh data-data yang mendukung kajian normatif ini, maka penelitian yang dilakukan adalah penelitian dengan menggunakan metode penelitian kepustakaan (Library Research Methods), kemudian dianalisis secara kualitatif berdasarkan bahan hukum primer (peraturan perundang-undangan, yurisprudensi dan putusan pengadilan), bahan hukum sekunder (bahan hukum pustaka dan jurnal ilmiah, serta bahan hukum tersier (kamus hukum).

\section{PEMBAHASAN}

\section{Bentuk Penyalahgunaan Wewenang Pejabat Pemerintah Yang Tidak Dapat Dipidana.}

Istilah wewenang atau kewenangan disejajarkan dengan "authority" dalam bahasa Inggris dan "bevoegdheid" dalam bahasa Belanda. Authority dalam Black's law Dictionary" diartikan sebagai legal power; a right to command or to act; the right and power of public officers to require obediennce to their orders lawfully issued in scope of their public duties. Menurut Abdul latif Kewenangan atau wewenang adalah konsep hukum publik, wewenang merupakan suatu konsep inti dalam Hukum Tata Negara atau Hukum Administrasi Negara. Jadi dalam konsep hukum publik wewenang berkaitan dengan kekuasaan. ${ }^{2}$ Dalam Undang Undang Administrasi Pemerintahan Pasal 1 Ketentuan Umum disebutkan, Wewenang adalah hak yang dimiliki oleh Badan dan/atau Pejabat Pemerintahan atau penyelenggara negara lainnya untuk mengambil keputusan dan/atau tindakan dalam penyelenggaraan pemerintahan. ${ }^{3}$ Sedangkan menurut Aminuddin Ilmar Wewenang adalah kemampuan untuk melakukan tindakan-tindakan hukum tertentu. ${ }^{4}$

Hukum administrasi negara mengatur tata cara satu perbuatan administrasi negara,

\footnotetext{
${ }^{1}$ Henry Campbell Black. (1990). Black's Law Dictionary. West Publishing. h.3

2 Abdul Latif. (2014). Hukum Administrasi Dalam Praktik Tindak Pidana Korupsi. Edisi Pertama, Kencana, Jakarta. h. 46.

3 Undang-Undang Administrasi Pemerintahan No. 30 tahun 2014 Pasal 1 Ketentuan Umum Pengertian Wewenang.

${ }^{4}$ Aminuddin Ilmar. (2013). Hukum Tata Pemerintahan, Identitas Universitas Hasanuddin, Makassar. h.115-116. 
diputus atau prosedur yang harus ditempuh, serta menentukan bidang substansi atau objek perbuatan administrasi yang menjadi wewenangnya. Dalam kapasitas sebagai pejabat administrasi, seseorang harus melakukan kewajibannya dan melaksanakan kewajiban tersebut dengan cara menggunakan wewenang yang dipunyai untuk melakukan perbuatan sesuai dengan prosedur yang diwajibkan.

Menurut Harjono ${ }^{5}$, sebagai pejabat orang yang berwenang menjalankan jabatannya dalam melaksanakan kewajibannya dapat saja salah dalam penggunaan wewenang (misuse of authority) atau bisa juga melakukan penyalahgunaan wewenang (abuse the powers), dimana kedua tindakan tersebut terdapat perbedaan yang mendasar. Kesalahan dalam penggunaan wewenang (misuse of authority) timbul karena kekurang cermatan, tidak saksama dalam membuat atau melakukan keputusan/tindakan dengan tanpa maksud tertentu, kecuali untuk menjalankan kewajiban.

Kesalahan dalam membuat keputusan/tindakan macam ini biasanya terjadi dalam memenuhi prosedur yang disyaratkan, yang sering disebut sebagai kesalahan administrasi. Kesalahan seperti ini dapat dilakukan perbaikan dengan maksud mengembalikan pada prosedur yang seharusnya. ${ }^{6}$ Sedangkan Penyalahgunaan Wewenang (abuse the powers) dilakukan dengan kesengajaan menyimpangkan tujuan pemberian wewenang kepada tujuan lain, demi kepentingan pribadi atau orang lain, yang mana penyalahgunaan wewenang ini pula pada praktiknya dapat mengakibatkan kerugian keuangan negara atau perekonomian negara. ${ }^{7}$

Hal itu senada dengan pendapat Philipus M. Hadjon, ${ }^{8}$ yang menyatakan dalam mengukur apakah telah terjadi penyalahgunaan wewenang, haruslah dibuktikan secara faktual

\footnotetext{
${ }^{5}$ Harjono, Dalam Keterangan Ahli Pada Persidangan Di Mahkamah Konstitusi Yang Dikutip Dari Putusan Mahkamah Konstitusi Nomor: 25/PUU-XIV/2016., h.43-44.

${ }^{6}$ Ibid.

${ }^{7}$ Ibid.

${ }^{8}$ Philipus M. Hadjon, et.al., (2010). Hukum administrasi dan Good Governance, Universitas Trisakti: Jakarta. h. 26.
} 
bahwa pejabat telah menggunakan wewenangnya untuk tujuan lain. Terjadinya penyalahgunaan wewenang bukanlah karena suatu kealpaan. Penyalahgunaan wewenang dilakukan secara sadar yaitu mengalihkan tujuan yang telah diberikan kepada wewenangnya itu. Pengalihan tujuan didasarkan atas interest pribadi, baik untuk kepentingan dirinya sendiri ataupun untuk orang lain.

Suatu wewenang bersumber dari undang-undang (atribusi), pelimpahan (delegasi) atau penugasan (mandat). Penyalahgunaan wewenang hanya mungkin dilakukan oleh mereka yang memperoleh wewenang atas dasar atribusi dan delegasi. Dalam hal mandat, pihak yang mungkin menyalahgunakan wewenang adalah mandans (pemberi tugas) dan bukan mandataris (pelaksana tugas). Pihak yang diberi dan yang menyalahgunakan wewenang adalah pihak yang dibebani tanggungjawab hukum. Hal ini sejalan dengan asas hukum "geen bevoegdheid zonder verantwoordelijkheid dan geen verantwordelijkheid zonder verantwoording" (tidak ada kewenangan tanpa pertanggungjawaban dan tidak ada pertanggungjawaban tanpa kewajiban). Pihak pelaksana tugas (mandataris) tidak dilekati wewenang, karena itu tidak dibebani tanggungjawab hukum. ${ }^{9}$

Pada perkara dugaan Tindak Pidana Korupsi dana nonbujeter Badan Urusan Logistik (Bulog) tahun 1999, yang mendudukkan Ir. Akbar Tandjung sebagai terdakwa dalam kapasitasnya sebagai Sekretaris Negara. Dalam Putusan No. 572/K/Pid/2003 ${ }^{10}$ Mahkamah Agung menjatuhkan putusan bebas kepada Ir. Akbar Tandjung karena tidak terbukti secara sah dan meyakinkan bersalah melakukan tindak pidana korupsi. Mahkamah Agung dalam pertimbangannya antara lain menyatakan Perbuatan yang telah dilakukan Terdakwa I selaku Mensesneg menurut Mahkamah Agung adalah pelaksanaan suatu perintah jabatan yang diberikan oleh kekuasaan yang berwenang, dalam hal ini adalah Presiden RI (Ir. Habibie). Serta adanya fakta hukum keluarnya dana dari Bulog sampai diterima oleh Ir. Akbar

\footnotetext{
${ }^{9}$ Ridwan H.R, 2010. Hukum Administrasi Negara Edisi Revisi, RajaGrafindo Persada, Jakarta. h. 383.

${ }^{10}$ Putusan Mahkamah Agung No. 532/k/pid /2003 Tanggal 12 Februari 2004.
} 
Tandjung dinilai oleh Mahkamah Agung merupakan tanggung jawab presiden Habibie langsung, karena inisiatif pengeluaran dana dari presiden. ${ }^{11}$ Jadi Mensesneg selaku staf pendukung Presiden hanya menjalankan perintah presiden sehingga berlaku asas vicorous liability (tanggung jawab atasan). Untuk itu Ir. Akbar Tandjung sebagai Mensesneg, hanyalah sebagai pelaksana perintah atasan dan tidak dapat dipidana karena tidak terdapat kesalahan yang dapat dipidana dalam tindakannya menjalankan perintah atasan tersebut. Perkara ini menjadi yurisprudensi Mahkamah Agung yang mempertegas jika Pihak pelaksana tugas (mandataris) tidak dilekati wewenang, karena itu tidak dibebani tanggungjawab hukum.

Sejak diterbitkannya Undang Undang Administrasi Pemerintahan Terdapat perbedaan mengenai penyalahgunaan wewenang dengan yang diatur dalam Undang Undang Pemberantasan Tindak Pidana Korupsi, karena penyalahgunaan wewenang dalam Undang Undang Administrasi Pemerintahan sebenarnya yang dimaksud adalah kesalahan dalam penggunaan wewenang (misuse of authority) ${ }^{12}$.Menurut Penulis kesalahan dalam penggunaan wewenang (misuse of authority) bisa berubah menjadi penyalahgunaan wewenang (abuse of power) sebagaimana yang dimaksud dalam Undang Undang Pemberantasan Tindak Pidana Korupsi, jika pejabat pemerintah pengguna wewenang ternyata melakukan kesengajaan untuk menyimpang dari tujuan pemberian wewenang kepada tujuan lain, demi keuntungan pribadi atau orang lain atau suatu koorporasi dengan memanfaatkan jabatan atau kedudukan yang mengakibatkan kerugian keuangan negara atau perekonomian negara. Menurut Yulius ketentuan penyalahgunaan wewenang dalam Undang Undang Administrasi Pemerintahan, walaupun berada dalam rumpun Hukum Administrasi Negara dimaksudkan sebagai sarana pemberantasan tindak pidana korupsi melalui tindakan pencegahan (preventif) dengan pendekatan reformasi birokrasi. ${ }^{13}$

\footnotetext{
11 ibid.

12 Op. Cit. harjono, h.44.

13 Yulius. (2015). Perkembangan Pemikiran dan Pengaturan Penyalahgunaan Wewenang di Indonesia (Tinjauan Singkat Dari Perspektif Hukum Administrasi Negara Pasca Berlakunya Undang-Undang Nomor 30 
Undang Undang Administrasi Pemerintahan mengkategorikan bentuk penyalahgunaan wewenang kedalam 3 bentuk, yaitu a) Melampaui wewenang, jika keputusan dan/atau tindakan yang dilakukan melampaui masa jabatan atau batas waktu berlakunya wewenang, melampaui batas wilayah berlakunya wewenang dan/atau bertentangan dengan ketentuan peraturan perundang-undangan b) Mencampuradukkan wewenang, jika keputusan dan/atau tindakan yang dilakukan diluar cakupan bidang atau materi wewenang yang diberikan dan/atau bertentangan dengan tujuan wewenang yang diberikan c) Bertindak sewenangwenang, jika keputusan dan/atau tindakan yang dilakukan tanpa dasar kewenangan bertentangan dengan putusan pengadilan yang berkekuatan hukum tetap. Dari ketentuan tersebut, Mohammad Sahlan berpendapat, Pengertian "menyalahgunakan kewenangan" ditekankan pada penyimpangan tujuan dari pemberian kewenangan tersebut (penyimpangan asas spesialitas), walaupun pada beberapa pengertian ditambahkan dengan unsur lain seperti penyalahgunaan prosedur dan perbuatan yang dilakukan tanpa wewenang/kewenangan. ${ }^{14}$ Jadi, didalam Undang Undang Administrasi Pemerintahan terdapat 2 pengertian lain terhadap penyalahgunaan wewenang, selain daripada penyimpangan tujuan pemberian wewenang (mencampuradukan kewenangan), yakni pada bentuk penyalahgunaan prosedur (melampaui wewenang) dan perbuatan yang dilakukan tanpa wewenang (bertindak sewenang -wenang).

Dari ketiga bentuk penyalahgunaan wewenang menurut Undang Undang Administrasi Pemerintahan tersebut, menurut penulis hanya bentuk perbuatan mencampuradukkan kewenangan yang dapat ditindaklanjuti sebagai tindak pidana korupsi, karena sebagaimana definisi klasik tentang penyalahgunaan wewenang, yakni sebagai perbuatan penggunaan wewenang yang dialihkan kepada tujuan lain yang bertetangan dengan tujuan pemberian wewenang. Dalam Undang Undang Pemberantasan Tindak Pidana Korupsi pengalihan tujuan

Tahun 2014), Artikel dalam Jurnal Hukum dan Peradilan, Badan Penelitian dan Pengembangan Hukum dan Peradilan Mahkamah Agung RI, Volume 04 Nomor 3 November 2015. Jakarta. h. 364.

${ }^{14}$ Mohammad Sahlan. (2016). Unsur Menyalahgunakan Kewenangan dalam Tindak Pidana Korupsi sebagai Kompetensi Absolut Peradilan Administrasi. Biro Hukum dan Organisasi, Kementerian Kelautan dan Perikanan Jurnal Hukum Ius Quia Iustum No. 2 Vol. 23 April 2016. Jakarta Pusat.h. 284. 
ini merupakan unsur utama dapat dipidananya perbuatan penyalahgunaan wewenang. Maka disini pengalihan tujuan pemberian wewenang itu, menurut penulis menjadi kata kunci untuk penilaian apakah suatu perbuatan penyalahgunaan wewenang pejabat pemerintah dapat ditindaklanjuti sebagai tindak pidana korupsi atau tidak,

Lain halnya dengan bentuk perbuatan dalam kategori melampaui wewenang dan bertindak sewenang-wenang sebagai bentuk lain penyalahgunaan wewenang dalam Undang Undang Administrasi Pemerintahan, bentuk penyalahgunaan wewenang dalam kedua spesies itu, bukanlah kategori bentuk penyalahgunaan wewenang yang dapat ditindaklanjuti sebagai tindak pidana korupsi, karena kategori melampaui wewenang dan bertindak sewenangwenang dalam Undang Undang Administrasi Pemerintahan pengertiannya tidak memuat unsur pengalihan tujuan pemberian wewenang. Jadi, bentuk melampaui wewenang dan bertindak sewenang-wenang hanya termasuk sebagai kesalahan adminisitrasi sebagai wujud perbuatan Kesalahan dalam penggunaan wewenang (misuse of authority). Sedangkan pada bentuk mencampuradukkan wewenang, selain merupakan kesalahan administrasi, dimungkinkan terdapat pula tindak pidana didalamnya, jika perbuatan pengalihan tujuan wewenang, dialihkan kepada tujuan mencari keuntungan yang merugikan keuangan negara atau perekonomian negara.

Kesalahan dalam penggunaan wewenang (misuse of authority) yang juga disebut sebagai penyalahgunaan wewenang dalam Undang Undang Administrasi Pemerintahan sebagaimana telah dijelaskan diatas, tidak sama dengan pengertian penyalahgunaan kewenangan (abuse of power) dalam Undang Undang Pemberantasan Tindak Pidana Korupsi, Akibat hukum dalam Undang Undang Administrasi Pemerintahan tentang penyalahgunaan wewenang yang merupakan Kesalahan dalam penggunaan wewenang (misuse of authority) ini adalah keputusan/tindakan dari pejabat pemerintah dapat dianggap tidak sah atau dapat dibatalkan. 
Dalam Pasal 19 Undang Undang Administrasi Pemerintahan menyatakan untuk keputusan dan/atau tindakan yang dilakukan secara melampaui wewenang dan secara sewenang-wewenang dianggap tidak sah, jika telah diuji dan ada putusan pengadilan yang berkekuatan hukum tetap. Kemudian untuk keputusan dan/atau tindakan yang dilakukan secara mencampuradukkan wewenang, dapat dibatalkan jika telah diuji dan ada putusan pengadilan yang berkekuatan hukum tetap.

Maka atas ketentuan tersebut hukum administrasi telah memberikan akibat hukum yang jelas kepada keputusan/tindakan pejabat pengguna wewenang yang dianggap melakukan penyalahgunaan wewenang. Namun jika memang terdapat pula peralihan tujuan dalam penggunaan wewenang yang berimplikasi pada suatu tindak pidana, maka dapat dilanjutkan dengan proses pidana sesuai dengan ketentuan Undang Undang Pemberantasan Tindak Pidana Korupsi, tapi hanya dimungkinkan untuk penyalahgunaan wewenang yang berkaitan dengan peralihan tujuan pemberian wewenang, yakni dengan kategori mencampuradukkan wewenang.

\section{Bentuk Kesalahan Dalam Penyalahgunaan Wewenang Pejabat Pemerintah Yang Dapat dipidana.}

Delik penyalahgunaan wewenang dalam tindak pidana korupsi diatur dalam pasal 3 Undang Undang Pemberantasan Tindak Pidana Korupsi yang rumusannya adalah Setiap orang dengan tujuan menguntungkan diri sendiri atau orang lain atau suatu koorporasi, menyalahgunakan kewenangan, kesempatan atau sarana yang ada padanya karena jabatan atau kedudukan yang dapat merugikan keuangan negara atau perekonomian negara, merupakan tindak pidana korupsi.

Rumusan tindak pidana korupsi tersebut, dapat diartikan sebagai aparatur negara atau pejabat publik dilarang melakukan penyalahgunaan wewenang dengan tujuan mencari keuntungan yang mana tujuan itu tidak sesuai dengan tujuan pemberian wewenang kepada 
pejabat tersebut. Pengertian apa yang dimaksud menguntungkan adalah sama dengan mendapat untung yaitu pendapatan yang diperoleh lebih besar daripada pengeluaran. Dalam rumusan pasal ini pula, keuntungan merupakan tujuan utama yang menjadi sebab penyalahgunaan wewenang atau dengan kata lain unsur delik Pasal 3 Undang Undang Pemberantasan Tindak Pidana Korupsi tersebut mempersyaratkan "tujuan" pelaku. Tidak hanya di Indonesia, di China Korupsi juga mempersyaratkan tujuan pelaku, sebagaimana diungkap Xixi Liu yang berpendapat "Corruption is the only government official acts of abuse of power, this concept that corruption includes the subject of corruption, motivation (purpose), mean, the way and the consequences and puts the negative corruption into the scope of corruptions"

Unsur dengan tujuan ini juga merupakan unsur tentang kesalahan pembuat pidana. Kesalahan dalam hukum pidana menjadi penentu dapat tidaknya seseorang dipertanggungjawabkan secara pidana. Kesalahan dalam hukum pidana dapat dibedakan dalam dua bentuk, yaitu kesalahan dalam bentuk kesengajaan (dolus atau opzet) dan kesalahan dalam bentuk kealpaan (culpa). Terkadang dalam suatu pasal kedua bentuk kesalahan itu dirumuskan secara alternatif atau salah satu bentuk kesalahan disebutkan secara tegas dalam suatu pasal. Menurut Satria Nugraha ${ }^{16}$, dirumuskannya unsur delik "dengan tujuan menguntungkan diri sendiri, orang lain, atau suatu korporasi" maka delik tersebut merupakan delik kesengajaan (dolus), delik kesengajaan dalam bentuk kesengajaan tingkat I (kesengajaan dengan maksud).

Dalam Pasal 3 Undang Undang Pemberantasan Tindak Pidana Korupsi, tegas digunakan frasa "dengan tujuan" frasa ini sama dengan kata "dengan maksud" hal ini

\footnotetext{
${ }^{15}$ Xizi Liu.(2016). A literature Review On The Definition Of Corruption And Factors Affecting The Risk Of Corruption. School Of Government, Beijing Normal University, Scientific Research An Academic Publisher Vol. 4 No.6, June 2016. Beijing, China.

16 Satriya Nugraha. (2016). Konsep Penyalahgunaan Wewenang Dalam Undang-Undang Tindak Pidana Korupsi Di Indonesia Fakultas Hukum, Universitas PGRI Palangka Raya. Jurnal Socioscientia. Palangka Raya. h. 21
} 
bermakna bentuk kesalahan dalam rumusan pasal tersebut adalah kesengajaan sebagai maksud. Bentuk kesalahan seperti ini adalah kesengajaan dalam arti sempit seperti yang ada pada pemerasan, pengancaman, maupun penipuan $(368,369,378$ KUHP). Dengan Tujuan adalah merupakan suatu kehendak yang masih dalam alam pikiran saja. Jika dihubungkan dengan tujuan untuk menguntungkan diri sendiri, atau orang lain atau suatu korporasi (unsur subjektif), maka jelas kehendak seperti itu adalah berupa kehendak yang tercela, suatu kehendak yang bersifat melawan hukum. Sifat melawan hukum (yang subjektif) tersebut disebabkan karena untuk pencapaiannya dilakukan dengan perbuatan penyalahgunaan wewenang. Dengan tujuan adalah merupakan tujuan dekat, suatu tujuan yang menurut akal dapat dicapai dengan melakukan suatu perbuatan tertentu. Tujuan dekat terdapat dalam kesengajaan sebagai maksud (opzet als oogmerk) atau dengan menggunakan istilah lain misalnya dengan tujuan, menghendaki dan istilah yang menggambarkan kehendak si pembuat. Tujuan dekat atau tujuan jauh (motif), menjadi penting dan perlu dibuktikan apabila dicantumkan sebagai unsur tindak pidana. Apabila tidak dicantumkan, tidak perlu dibuktikan.

Dalam pasal 3 Undang-Undang Pemberantasan Tidak Pidana Korupsi, karena terdapat frasa dengan tujuan maka harus dibuktikan. Itulah mengapa tujuan merupakan penilaian utama apakah pejabat pemerintah dalam mengunakan wewenangnya memang dengan sengaja sebagai maksud untuk melakukan penyalahgunaan wewenang. Hal ini juga mempertegas bahwa bentuk kesalahan pembuat/pelaku menjadi penentu dari apakah seseorang dapat dipertanggungjawabkan secara pidana atau tidak.

Kembali pada Pada perkara dugaan Tindak Pidana Korupsi dana nonbujeter Badan Urusan Logistik (Bulog) tahun 1999, yang mendudukkan Akbar Tandjung sebagai terdakwa dalam kapasitasnya sebagai Sekretaris Negara, sebagaimana telah dijelaskan pada pembahasan sebelumnya. Dalam Putusan No. 572/K/Pid/2003 Mahkamah Agung yang menjatuhkan putusan bebas kepada Ir. Akbar Tandjung. Mahkamah Agung dalam 
pertimbangannya antara lain menyatakan, haruslah dibuktikan terlebih dahulu unsur pokok dalam hukum pidana apakah terdakwa mempunyai kesengajaan (opzet) untuk melakukan perbuatan penyalahgunaan wewenang tersebut, dan bahwa memang terdakwa menghendaki dan mengetahui (met willens and wetens) bahwa perbuatan itu dilarang tapi tetap dilakukannya. ${ }^{17}$

Perbuatan yang telah dilakukan Terdakwa I selaku Mensesneg menurut Mahkamah Agung adalah pelaksanaan suatu perintah jabatan yang diberikan oleh kekuasaan yang berwenang, dalam hal ini adalah Presiden RI B.J. Habibie. Serta adanya fakta hukum keluarnya dana dari Bulog sampai diterima oleh Akbar Tandjung dinilai oleh Mahkamah Agung merupakan tanggung jawab presiden Habibie langsung, karena inisiatif pengeluaran dana dari presiden. ${ }^{18}$ Jadi Mensesneg selaku staf pendukung Presiden hanya menjalankan perintah presiden sehingga berlaku asas vicorous liability (tanggung jawab atasan). Untuk itu Akbar Tandjung sebagai Mensesneg, hanyalah sebagai pelaksana perintah atasan dan tidak dapat dipidana karena tidak terdapat kesalahan yang dapat dipidana dalam tindakannya menjalankan perintah atasan tersebut.

Dari perkara Akbar Tandjung tersebut, jelas jika kesalahan menjadi hal yang penting dalam suatu pertanggungjawaban pidana, bahkan Mahkamah Agung turut pula menekankan pentingnya pembuktian terlebih dahulu tentang kesalahan terdakwa apakah terdakwa mempunyai kesalahan dalam bentuk kesengajaan (opzet) atau bentuk kesalahan lainnya, atau sama sekali tidak melakukan kesalahan dalam bentuk apapun. Pemidanaan hanya dapat dilakukan ketika seseorang melakukan tindak pidana dengan kesalahan. Kesalahan ditandai oleh adanya kesengajaan atau kealpaan pada pembuatnya. Bentuk-bentuk kesalahan ini juga menjadi pembatas dalam penjatuhan pidana.

Sejak berlakunya Undang Undang Administrasi Pemerintahan, apabila terjadi penilaian

\footnotetext{
${ }_{17}^{17}$ Putusan Mahkamah Agung No. 532/k/pid/2003 tanggal 12 februari 2004.

${ }^{18}$ ibid.
} 
terhadap penyalahgunaan wewenang, maka penyelesaian terlebih dahulu seharusnya dilakukan oleh Aparat Pengawasan Intern Pemerintahan (APIP) dengan menilai apakah terdapat kesalahan penggunaan kewenangan, terdapat kesalahan administrasi, atau terdapat kesalahan administrasi yang merugikan keuangan negara. Jika APIP menemukan adanya kesalahan administratif yang menimbulkan kerugian keuangan negara maka prosedur pertama yang perlu dilakukan adalah rekomendasi kepada pejabat yang melakukan penyalahgunaan wewenang untuk melakukan pengembalian kerugian keuangan negara paling lama 10 (sepuluh) hari kerja terhitung sejak diputuskan dan diterbitkannya hasil pengawasan. $^{19}$

Menurut Efendi ada dualisme mekanisme penyelesaian hukum perkara penyalahgunaan wewenang antara hukum pidana korupsi berdasarkan Undang Undang Pemberantasan Tindak Pidana Korupsi dengan hukum administrasi berdasarkan Undang Undang Administrasi Pemerintahan ini menjadikan penanganan tindakan penyalahgunaan wewenang tidak sesuai dengan asas kepastian hukum. Dapat saja tindakan penyalahgunaan wewenang oleh Badan atau Pejabat Pemerintahan yang sudah diselesaikan dengan mekanisme hukum administrasi kemudian masih berlanjut menjadi perkara delik korupsi. ${ }^{20}$ Penulis tidak sependapat dengan pendapat tersebut, karena sebagaimana yang telah penulis jelaskan sebelumnya, bahwa penyalahgunaan wewenang yang diatur dalam Undang Undang Administrasi Pemerintahan dengan yang diatur oleh Undang Undang Pemberantasan Tindak Pidana Korupsi merupakan pengertian yang berbeda, namun saling melengkapi. Lebih tepatnya menurut penulis penyelesaian penyalahgunaan wewenang sesuai Undang Undang Administrasi Pemerintahan adalah langkah preventif atas penilaian pengunaan wewenang pejabat sebelum proses pidana.

\footnotetext{
${ }^{19}$ Ahmad Rustan Syamsuddin. (2020). Pembuktian Penyalahgunaan Wewenang Dalam Perkara Tindak Pidana Korupsi Pengadaan Barang dan Jasa. Fakultas Hukum Universitas Muhammadiyah Kendari. Kendari.

${ }^{20}$ Efendi. (2019). Interpretasi Modern Makna Menyalahgunakan Wewenang Dalam Tindak Pidana Korupsi Kajian Putusan Nomor 977 K/Pid/2004 Fakultas Hukum Universitas Jember. Jurnal Jalrev. Jember. h.341 
Hal ini senada dengan pendapat Shobirin ${ }^{21}$, yang menyatakan terjadi pergeseran politik hukum pemerintah dalam upaya pemberantasan Tindak pidana korupsi yang dilakukan oleh penyelenggara negara. Saat ini, pemerintah cenderung melakukan penyeimbangan antara upaya pencegahan (preventif) dengan upaya penindakan (represif).

Maka menurut penulis esensinya penyelesaian administrasi harus sesuai dengan asas contrarius actus, untuk itu harus diberikan kesempatan hukum administrasi menyelesaikan terlebih dahulu. Menurut Enrico Parulian Simanjuntak ${ }^{22}$, Interelasi antara hukum pidana dengan hukum administrasi menunjukkan persamaan sekaligus perbedaan kriteria penyalahgunaan wewenang dalam kedua cabang hukum ini. Dalam hukum pidana ruang lingkup penyalahgunaan wewenang lebih sempit dibandingkan dengan hukum administrasi namun parameter terjadinya penyalahgunaan wewenang dalam hukum pidana lebih luas dibandingkan hukum administrasi.

Upaya hukum apabila aparatur penegak hukum atau badan pemerintah keberatan atas penilaian APIP, maka dapat dilakukan pengujian di Pengadilan Tata Usaha Negara. Hal yang sudah diatur pelaksanaannya dengan Peraturan Mahkamah Agung Nomor 5 Tahun 2015. Badan dan/atau pejabat pemerintahan yang merasa kepentingan dirugikan oleh hasil pengawasan juga dapat mengajukan ke Pengadilan Tata Usaha Negara. Dalam pengujian unsur penyalahgunaan wewenang yang dapat bertindak sebagai pemohon adalah: 1) Badan pemerintahan atau Pejabat Pemerintahan; 2) Telah ada hasil pengawasan Aparat Pengawasan Intern Pemerintah (APIP) yang menyatakan ada kesalahan administratif yang menimbulkan kerugian keuangan negara; 3) Terjadi karena ada atau tidak ada unsur penyalahgunaan

\footnotetext{
${ }^{21}$ Shobirin. (2020). Penyalahgunaan Wewenang Jabatan Oleh Pejabat Negara/Pemerintah: Perspektif Hukum Administrasi Negara Dan Hukum Pidana. Fakultas Hukum Universitas Lancang Kuning. Journal Unilak. Riau. h. 116.

22 Enrico Parulian Simanjuntak. (2018). Pengujian Ada Tidaknya Penyalahgunaan Wewenang Menurut Undang-Undang Administrasi Pemerintahan. Ditjen Badan Peradilan Militer dan Tata Usaha Negara MA-RI Jakarta Pusat. Jurnal Hukum dan Peradilan, Volume 7 Nomor 2 Juli 2018. Jakarta.h. 259
} 
wewenang. ${ }^{23}$

Menindaklanjuti pemberian wewenang kepada Pengadilan Tata Usaha Negara tersebut di atas, maka Mahkamah Agung Republik Indonesia mengeluarkan Peraturan Mahkamah Agung Nomor 4 Tahun 2015 tentang Pedoman Beracara Penilaian unsur Penyalahgunaan Wewenang. Dalam Peraturan Mahkamah Agung tersebut Kewenangan Pengadilan Tata Usaha Negara untuk mengadili permohonan penilaian ada tidaknya penyalahgunaan wewenang pejabat pemerintah dapat dilakukan sebelum adanya proses pidana. Hal tersebut menurut Henny Juliani memberikan kesan bahwa proses peradilan pidana dapat mengesampingkan proses peradilan administrasi. ${ }^{24}$

Penulis sepakat dengan pendapat Henny Juliani tersebut, karena ketentuan dalam Peraturan Mahkamah Agung Nomor 4 tahun 2015 itu justru tidak sesuai dengan Undang Undang Administrasi Pemerintahan, karena didalam Undang Undang Administrasi Pemerintahan tidak ada satu ketentuanpun yang menyatakan jika Pengadilan Tata Usaha Negara hanya berwenang sebelum adanya proses pidana. Maka ketentuan Peraturan Mahkamah Agung yang bukan merupakan perintah dari Undang Undang Administrasi Pemerintahan, menurut Penulis dapat dikesampingkan, oleh karenanya Pengadilan Tata Usaha Negara tetap berwenang memeriksa permohonan penyalahgunaan wewenang pejabat pemerintah meskipun proses pidana (penyidikan) sudah dimulai.

Namun jika Peraturan Mahkamah Agung tersebut ingin dipatuhi, maka menurut penulis harus ditafisrkan jika proses pidana yang dimaksud adalah proses pidana pada Pengadilan Tindak Pidana Korupsi dan bukan proses pidana yang dilakukan sejak penyidikan sebagaimana praktiknya selama ini, karena Peraturan Mahkamah Agung hanya bisa mengatur

\footnotetext{
${ }^{23}$ Firna Novi Anggoro. (2016). Pengujian Unsur Penyalahgunaan Wewenang Terhadap Keputusan Dan/Atau Tindakan Pejabat Pemerintahan Oleh Pengadilan Tata Usaha Negara. Badan Pusat Statistik Provinsi Lampung. Fiat Justisia Jurnal Ilmu Hukum Volume 10 Number 4, October-December 2016 Lampung. h. 655

${ }^{24}$ Henny Juliani. (2019). Akibat Hukum Penyalahgunaan Wewenang Administrasi Pejabat Pemerintahan yang Menimbulkan Kerugian Keuangan Negara. Fakultas Hukum, Universitas Diponegoro. Adminitrative Law \& Governance Journal. Volume 2 Issue 4, Nov 2019 Semarang. h.607
} 
internal dari badan Peradilan di Mahkamah Agung, maka penilaian ada tidaknya penyalahgunaan wewenang pejabat pemerintah, tetap dapat dilakukan oleh Pengadilan Tata Usaha Negara sebelum proses pidana yakni perkara dilimpahkan kepada Pengadilan Tindak Pidana Korupsi.

Berdasarkan penelitian yang dilakukan Dian Puji N Simatupang sebagaimana dikutip oleh fathudin ${ }^{25}$, terungkap sebanyak 70 persen kasus hukum yang terjadi yang menyangkut tentang kebijakan publik justru bersifat dwaling (salah kira). Sementara hanya 30 persen saja yang murni mengandung unsur pidana. Inilah alasan mengapa sangat penting untuk menilai penyalahgunaan wewenang dengan pengujian menggunakan sarana hukum administrasi dan menempatkan hukum pidana sebagai ultimum remedium.

Pemidanaan atas penyalahggunaan wewenang pejabat pemerintah haruslah merupakan upaya/sanksi terakhir (ultimum remidium), yang dimaksudkan selain memberikan kepastian hukum, juga agar proses hukum pidana yang dapat melakukan perampasan kemerdekaan, perampasan harta benda, bahkan perampasan nyawa, dapat dilakukan secara terukur dan berhati-hati, karena hal itu terkait dengan kebijakan peniadaan kemerdekaan dari hak asasi manusia yang dilegalisasi oleh undang-undang.

\section{SIMPULAN}

Bentuk Penyalahgunaan Wewenang yang tidak dapat dipidana adalah penyalahgunaan wewenang dengan bentuk melampaui wewenang dan sewenang-wenang, karena dalam pengertiannya di Undang Undang Administrasi Pemerintahan tidak ada peralihan tujuan dari pemberian wewenang terkecuali merupakan kesalahan administrasi dengan wujud kesalahan penggunaan wewenang (misuse of authority). Sedangkan dalam Penyalahgunaan Wewenang yang dapat dipidana bentuk penyalahgunaan wewenangnya sesuai dengan pengertian dalam

\footnotetext{
${ }^{25}$ Fathudin. (2015). Tindak Pidana Korupsi (Dugaan Penyalahgunaan Wewenang) Pejabat Publik (Perspektif Undang-Undang Nomor 30 Tahun 2014 Tentang Administrasi Pemerintahan). Pusat Studi Konstitusi dan Legislasi Nasional (Posko-Legnas) Fakultas Syariah dan Hukum UIN Jakarta. Jurnal Cita Hukum. Vol. II No. 1 Juni 2015 Jakarta. h. 127
} 
Undang Undang Administrasi Pemerintahan tentang mencampuradukkan wewenang yang dapat ditindaklanjuti dengan pemidanaan ketika peralihan tujuan wewenang itu disertai Niat Jahat (Mens Rea) dalam bentuk kesalahan dengan corak kesengajaan sebagai maksud untuk mencari keuntungan yang merugikan keuangan Negara atau perekonomian Negara.

\section{DAFTAR PUSTAKA}

\section{BUKU}

Abdul Latif. (2014). Hukum Administrasi Dalam Praktik Tindak Pidana Korupsi, Edisi Pertama, Kencana, Jakarta.

Aminuddin Ilmar. (2013). Hukum Tata Pemerintahan, Identitas Universitas Hasanuddin, Makassar.

Henry Campbell Black. (1990). Black's Law Dictionary, west publishing.

Philipus M. Hadjon, et.al., (2010). Hukum administrasi dan Good Governance, Universitas Trisakti: Jakarta.

Ridwan H.R, 2010. Hukum Administrasi Negara Edisi Revisi, RajaGrafindo Persada, Jakarta.

\section{ARTIKEL JURNAL}

Ahmad Rustan Syamsuddin. (2020). Pembuktian Penyalahgunaan Wewenang Dalam Perkara Tindak Pidana Korupsi Pengadaan Barang dan Jasa. Fakultas Hukum Universitas Muhammadiyah Kendari. Kendari.

Efendi. (2019). Interpretasi Modern Makna Menyalahgunakan Wewenang Dalam Tindak Pidana Korupsi Kajian Putusan Nomor 977 K/Pid/2004 A Modern Interpretation Over The Abuse Of Authority In Corruption Fakultas Hukum Universitas Jember. Jember.

Enrico Parulian Simanjuntak. (2018). Pengujian Ada Tidaknya Penyalahgunaan Wewenang Menurut Undang-Undang Administrasi Pemerintahan. Ditjen Badan Peradilan Militer dan Tata Usaha Negara MA-RI Jakarta Pusat. Jakarta.

Fathudin. (2015). Tindak Pidana Korupsi (Dugaan Penyalahgunaan Wewenang) Pejabat Publik (Perspektif Undang-Undang Nomor 30 Tahun 2014 Tentang Administrasi Pemerintahan). Pusat Studi Konstitusi dan Legislasi Nasional (Posko-Legnas) Fakultas Syariah dan Hukum UIN Jakarta. Jakarta.

Firna Novi Anggoro. (2016). Pengujian Unsur Penyalahgunaan Wewenang Terhadap Keputusan Dan/Atau Tindakan Pejabat Pemerintahan Oleh PENGADILAN TATA USAHA NEGARA. Badan Pusat Statistik Provinsi Lampung. Lampung.

Henny Juliani. (2019). Akibat Hukum Penyalahgunaan Wewenang Administrasi Pejabat Pemerintahan yang Menimbulkan Kerugian Keuangan Negara. Fakultas Hukum, Universitas Diponegoro. Semarang.

Mohammad Sahlan. (2016). Unsur Menyalahgunakan Kewenangan dalam Tindak Pidana Korupsi sebagai Kompetensi Absolut Peradilan Administrasi. Biro Hukum dan Organisasi, Kementerian Kelautan dan Perikanan Jakarta Pusat. Jakarta. 
Satriya Nugraha. (2016). Konsep Penyalahgunaan Wewenang Dalam Undang-Undang Tindak Pidana Korupsi Di Indonesia Fakultas Hukum, Universitas PGRI Palangka Raya. Palangka Raya.

Shobirin. (2020). Penyalahgunaan Wewenang Jabatan Oleh Pejabat Negara/Pemerintah: Perspektif Hukum Administrasi Negara Dan Hukum Pidana. Fakultas Hukum Universitas Lancang Kuning. Riau.

Xizi Liu.(2016). A literature Review On The Definition Of Corruption And Factors Affecting The Risk Of Corruption. School Of Government, Beijing Normal University, Scientific Research An Academic Publisher Vol. 4 No.6, June 2016. Beijing, China.

Yulius. (2015). Perkembangan Pemikiran dan Pengaturan Penyalahgunaan Wewenang di Indonesia (Tinjauan Singkat Dari Perspektif Hukum Administrasi Negara Pasca Berlakunya Undang-Undang Nomor 30 Tahun 2014), Artikel dalam Jurnal Hukum dan Peradilan, Badan Penelitian dan Pengembangan Hukum dan Peradilan Mahkamah Agung RI, Volume 04 Nomor 3 November 2015. Jakarta.

\section{PUTUSAN PENGADILAN}

Putusan Mahkamah Agung No. 532/K/Pid/2003.

Putusan Mahkamah Konstitusi Nomor: 25/PUU-XIV/2016. 